\title{
Blood selenium concentrations and glutathione peroxidase activity
}

\author{
B LLOYD, ${ }^{*}$ E ROBSON, ${ }^{*}$ I SMITH, $\dagger$ AND B E CLAYTON* \\ *University Unit of Chemical Pathology and Human Metabolism, Southampton General Hospital, \\ Southampton, and IInstitute of Child Health, London
}

SUMMARY Selenium concentrations in children and teenagers without a metabolic disorder eating normal diets (group 1), and young patients with classical phenylketonuria and milder forms of hyperphenylalaninaemia being treated with a diet low in natural protein (group 2) were investigated. There was a strong correlation between blood selenium concentration and age in children in group 1 up to 10 years of age. Blood selenium concentrations and glutathione peroxidase activities were significantly lower in the patients who were receiving diets containing reduced amounts of natural protein, and the differences were more than would be expected for age. When the concentrations of selenium in blood from groups 1 and 2 were compared with glutathione peroxidase activity, a strong association was found when blood selenium concentrations were below $1.26 \mu \mathrm{mol} / \mathrm{l}$. Reduction in glutathione peroxidase activity may be harmful in the long term, and the addition of selenium to therapeutic diets is recommended.

Selenium exists naturally in food mainly as organic compounds such as the amino acids selenomethionine, selenocystine, and selenocysteine. ${ }^{1}$ The estimated dietary intakes of selenium in different countries vary considerably, resulting in wide divergence in blood selenium concentrations. ${ }^{2}$ Dietary intakes within the range 50-200 $\mu \mathrm{g} /$ day $(0.63-2.53 \mu \mathrm{mol})$ are considered adequate and safe for adults, ${ }^{3}$ and Thorn $e t a l^{4}$ reported an average intake of $60 \mu \mathrm{g} /$ day $(0.76 \mu \mathrm{mol})$ in the United Kingdom. The safe and adequate intake from 0 to 6 years varies with age within the range $10-120 \mu \mathrm{g},{ }^{5}$ but Lombeck et al noted that the selenium content of infant formulas based on cows' milk were lower than those of human or cows' milk samples. ${ }^{6}$ They concluded that infants receive between 3.5-13.3 $\mu \mathrm{g} /$ day of selenium according to the feed given. Severe reduction in intake of selenium in the general population in Britain does not occur, unlike some countries such as China. ${ }^{7}$

Selenium is an essential component of the enzyme glutathione peroxidase (EC 1.11.1.9), which functions as part of an antioxidant system to protect membranes and essential proteins from the potentially damaging effects of reactive oxygen and lipid peroxides. ${ }^{8}$ The intake of this element is therefore particularly important when considering therapeutic diets, parenteral nutrition, and the increasing intakes of convenience foods. Children with the more severe forms of hyperphenylalaninaemia, ${ }^{9}$ mainly classical phenylketonuria, receive a synthetic substitute in place of much of the natural dietary protein and therefore provide a suitable group in which to study the association between blood selenium concentrations and glutathione peroxidase activity. The synthetic protein substitutes are low in or free from selenium, which is also not included in the trace element supplements prescribed with such diets.

In this study the association between glutathione peroxidase activity and blood selenium concentrations was assessed in a wide range of measurements, firstly in order to determine the blood selenium concentration at which glutathione peroxidase activity is reduced in children. Secondly, we believe that the information provided will be useful when considering supplementation with selenium in synthetic diets. The subjects included children and teenagers (without metabolic disorders) receiving normal food as well as patients of varying degrees of severity who were receiving phenylalanine controlled diets.

The study had the approval of the joint ethical subcommittee of the Southampton and South West 
Hampshire Health Authority and the University of Southampton.

\section{Subjects and methods}

Group 1 comprised children and teenagers (without metabolic disorders) eating normal diets. As it is difficult to justify taking blood samples by venepuncture or finger prick from healthy children without a medical reason, we used specimens that had already been collected for other analyses. The samples were obtained from the following sources: Group 1a: local out patients $(n=59)$ at Southampton General Hospital, having routine haematological investigations for minor ailments. Group 1b: samples received at the hospital $(n=24)$ from many hospitals throughout the United Kingdom for routine measurement of blood lead concentrations. None of the specimens in this group had blood lead concentrations of more than $1.0 \mu \mathrm{mol} / 1$. Group $1 \mathrm{c}$ : blood samples from children in Greenwich $(n=20)$ which had formed part of an environmental project and were no longer required for further analysis. Group 1d: blood samples from children in inner London $(n=38)$, part of the same environment project.

Group 2 comprised children and teenagers with classical phenylketonuria and milder forms of hyperphenylalaninaemia. As it is customary to monitor the blood phenylalanine concentrations of patients with phenylketonuria or milder forms of hyperphenylalaninaemia at regular intervals, whether they are on a strict or free diet, a few extra drops of blood obtained by finger prick or heel prick were collected for this study provided consent had been given. The blood samples were therefore obtained from patients attending clinics at Southampton (group 2a, $n=16$ ) as well as the Hospital for Sick Children, Great Ormond Street, London (group 2b, $n=42$ ).
Whole blood samples were stored at $-20^{\circ} \mathrm{C}$ until analysis. Selenium was assayed by hydride generation and atomic absorption spectrophotometry, ${ }^{10}$ and the activity of glutathione peroxidase was measured within seven days of collection of the samples by the method of Beutler ${ }^{11}$ using t-butyl hydroperoxide as substrate. Only a limited number of specimens were suitable for glutathione peroxidase analysis as many of the specimens were too old, or too small.

The Mann-Whitney U test and regression analysis of the data were carried out on an IBM PC using the EPISTAT statistical package.

\section{Results}

The results for the children and teenagers in group 1 are shown in table 1 . The mean blood selenium concentrations and glutathione peroxidase activities were similar for subjects in group 1a and group 1d. Group 1b, however, had a lower mean selenium concentration and group 1c had a higher mean selenium concentration.

Because the mean ages and the age ranges of the subjects in the four groups varied considerably, a possible association between selenium concentration and age was studied by regression analysis, and the coefficient of correlation (r) was $0 \cdot 46$. The data were then reanalysed for children above and below 10 years of age. Fig 1 shows an increase in blood selenium concentration $(r=0.56)$ in children under 10 years old, but in the older subjects (10 to 19 years) there was no correlation between selenium and age $(r=0 \cdot 04)$.

Details of the patients in groups $2 a$ and $2 b$ together with their results are given in table 2 . The data were analysed according to diet and hospital. Blood selenium was significantly higher $(p<0.01)$ in the free diet groups from both hospitals $(p<0.001)$ than in the strict diet groups from either hospital.

Table 1 Selenium concentrations in children in group 1

\begin{tabular}{|c|c|c|c|c|}
\hline Group No & Sample source & $\begin{array}{l}\text { Mean (range) } \\
\text { age (years) }\end{array}$ & $\begin{array}{l}\text { Mean }(S D) \\
\text { blood selenium } \\
\text { concentration } \\
(\mu \text { mol/l) })\end{array}$ & $\begin{array}{l}\text { Mean }(S D) \\
\text { glutathione } \\
\text { peroxidase activity } \\
(\mathrm{U} / \mathrm{g} \mathrm{Hb})\end{array}$ \\
\hline $1 \mathrm{a}$ & Southampton & $13 \cdot 1(4-19)$ & $\begin{array}{l}1.33(0 \cdot 24) \\
(\mathrm{n}=59)\end{array}$ & $\begin{array}{l}16 \cdot 8(3 \cdot 1) \\
(n=42)\end{array}$ \\
\hline $1 b$ & Southampton* & $2 \cdot 3(0 \cdot 7-4)$ & $\begin{array}{l}0.99(0 \cdot 27) \\
(\mathrm{n}=24)\end{array}$ & Not measured \\
\hline 1c & Greenwich & $8 \cdot 2(3-15)$ & $\begin{array}{l}1.47(0 \cdot 26) \\
(n=20)\end{array}$ & Not measured \\
\hline 1d & Inner London & $6 \cdot 7(6-7)$ & $\begin{array}{l}1 \cdot 28(0 \cdot 14) \\
(n=38)\end{array}$ & $\begin{array}{l}16 \cdot 5(3 \cdot 5) \\
(n=31)\end{array}$ \\
\hline
\end{tabular}

${ }^{*}$ Blood samples analysed at Southampton General Hospital but received from many different towns. 


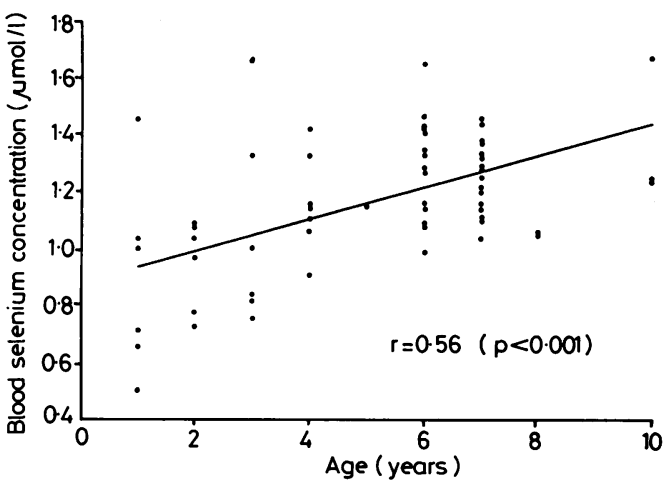

Fig 1 Correlation between blood selenium concentration and age in healthy children.
Glutathione peroxidase activities showed a similar pattern.

In order to assess the possible association between blood selenium concentrations and glutathione peroxidase activity, all the available results from patients in group 2 were combined with those of the subjects on a normal diet (group 1) to give a wide range of selenium concentrations. The complete data were first tested by regression analysis and gave a correlation coefficient of $0 \cdot 63$, then reanalysed taking blood selenium values below and above 1.26 $\mu \mathrm{mol} / \mathrm{l}$ separately. Fig 2 shows a good correlation between blood selenium concentrations and glutathione peroxidase activity when blood selenium concentrations were less than $1.26 \mu \mathrm{mol} / 1(\mathrm{r}=0.77$,

Table 2 Blood selenium concentrations glutathione peroxidase activity in relation to diet for patients in group 2

\begin{tabular}{|c|c|c|c|c|c|}
\hline Group No & Hospital & Diet & $\begin{array}{l}\text { Mean (range) } \\
\text { age (years) }\end{array}$ & $\begin{array}{l}\text { Mean }(S D) \\
\text { blood selenium } \\
\text { concentration } \\
(\mu \text { mollll) }\end{array}$ & $\begin{array}{l}\text { Mean }(S D) \\
\text { glutathione } \\
\text { peroxidase activity } \\
(\mathrm{U} / \mathrm{g} \mathrm{Hb})\end{array}$ \\
\hline $2 \mathbf{a}$ & Southampton General Hospital: & Free & $15 \cdot 3(11-18)$ & $\begin{array}{l}{ }^{*} 1.47 \\
(n=4)\end{array}(0.37)$ & $\begin{array}{l}* 14 \cdot 3 \\
(\mathrm{n}=3)\end{array}(2 \cdot 6)$ \\
\hline $2 b$ & Hospital for Sick Children: & $\begin{array}{l}\text { Free } \\
\text { Strict }\end{array}$ & $\begin{array}{l}6 \cdot 3(0 \cdot 66-17) \\
2 \cdot 1(0 \cdot 09-8)\end{array}$ & $\begin{array}{c}{ }^{* *} 1.26(0.59) \\
(n=9) \\
0.56(0.23) \\
(n=33)\end{array}$ & $\begin{array}{c}* * 11 \cdot 3(2 \cdot 6) \\
(n=6) \\
7 \cdot 3(2 \cdot 6) \\
(n=19)\end{array}$ \\
\hline
\end{tabular}

*Blood selenium concentrations and glutathione peroxidase activities were significantly higher in the patients on a free diet compared with those on a strict diet.

${ }^{*} \mathrm{p}<0 \cdot 01 ;{ }^{* *} \mathrm{p}<0 \cdot 001$

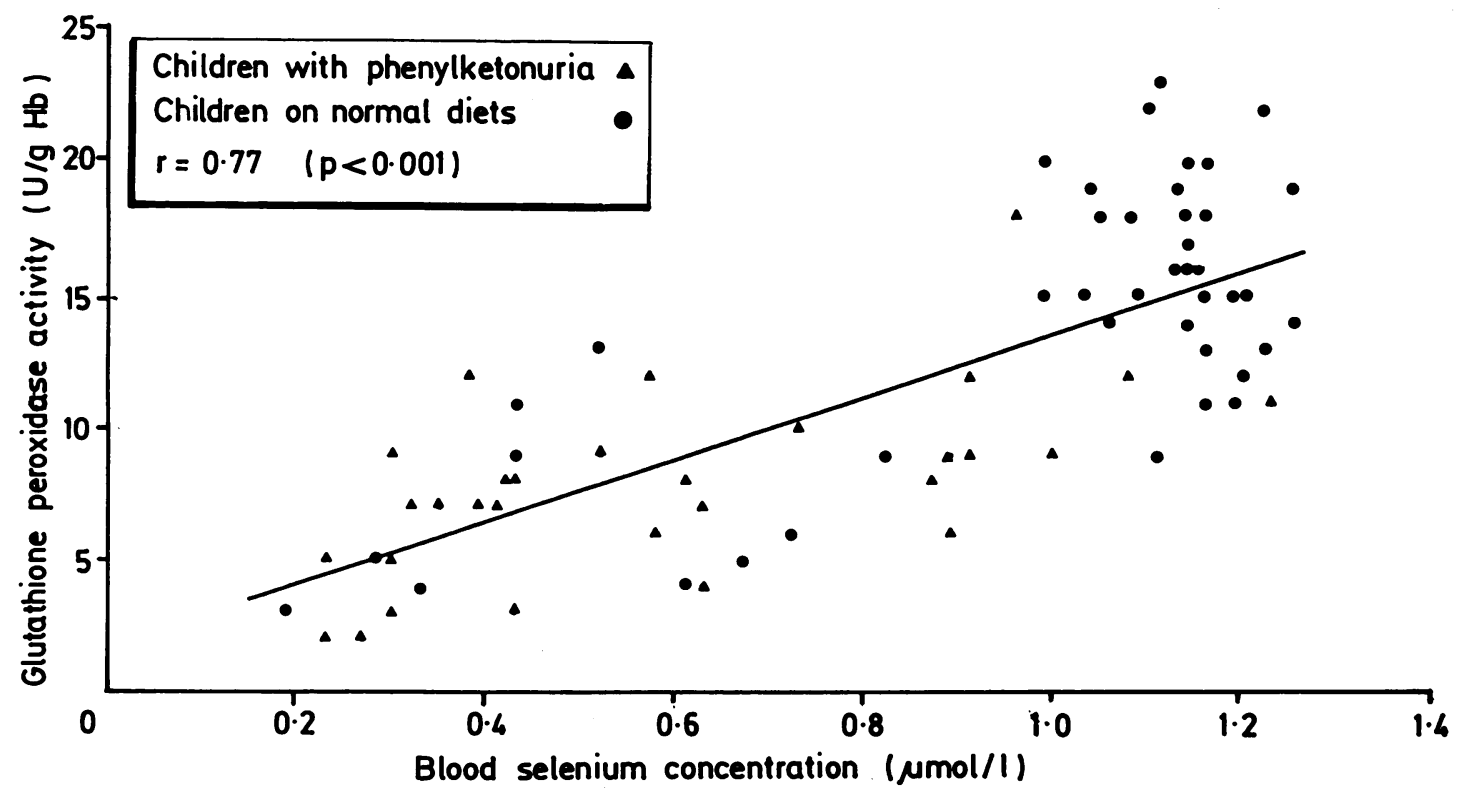

Fig 2 Correlation between blood selenium concentrations and glutathione peroxidase activities in children with phenylketonuria and those on normal diets. 
$\mathrm{p}<0 \cdot 001$ ). Above this concentration there was no correlation between blood selenium concentration and enzyme activity $(\mathrm{r}=-0 \cdot 16)$.

\section{Discussion}

The concentrations of selenium in blood from subjects eating normal food varied considerably. The differences may be solely a result of age, but different foods and ethnic backgrounds may have had an effect as a number of children were of Asian origin.

It has previously been reported that the lowest concentrations of serum selenium in healthy people have been found in infants 1-4 months old and that they increase thereafter with age until adult concentrations are reached. ${ }^{6-12}$ Modern practice is to feed infants with processed food rather than a home prepared diet, but information about the selenium content of processed infant food is limited. ${ }^{13}$ Morris and Levander, ${ }^{14}$ however, showed that processing caused a $40-50 \%$ reduction in the selenium content of strained infant food. In this study the upward trend in selenium concentration did not continue after 10 years of age, and may show that by this age the diet of the children was similar to that of adults, although Ward et $a l^{15}$ in an earlier study reported that adult levels of blood selenium seemed to have been achieved by the time the children were 5 or 6 years old.

Significant differences were found when blood selenium concentrations of patients with hyperphenylalaninaemia from both hospitals were compared according to diet. Generally patients on free diets were much older than those on a strict diet; however, the difference in selenium concentrations between the two groups was more than would be expected for age when compared with subjects on a normal diet. The low blood selenium concentrations and glutathione peroxidase activities of the children on strict diets were similar to those previously reported in areas of China where Keshan disease, an endemic cardiomyopathy, was common. ${ }^{16}$ Four children on strict diets were therefore examined by echocardiography but no abnormalities were seen. It has previously been reported that glutathione peroxidase activity in children with phenylketonuria controlled by diet and given selenium supplementation in the form of selenium yeast only achieved normal concentrations after $80-100$ days of supplementation. ${ }^{12}$ As yet no long term studies of selenium supplementation in children receiving synthetic diets have been reported as far as we know.

The enzyme requires the presence of selenocysteine in the active site ${ }^{17} 18$ and both experimental and clinical selenium deficiency have been shown to result in decreased glutathione peroxidase activity. ${ }^{19}$ In vitro kinetic measurements of glutathione peroxidase activity are unable to distinguish between an inactive enzyme and a lack of enzyme protein. Takahashi et $a l^{20}$ recently developed a polyclonal monospecific antibody that was used to show a direct association between glutathione peroxidase activity and protein content in the red cells of both normal and selenium deficient subjects. They suggested that there may be an association between selenium and synthesis of glutathione peroxidase protein, as a deficiency in selenium would result in a deficiency of selenocysteine required for the production of enzyme protein. ${ }^{21}$ Carmagnol et al reported that a high proportion of glutathione peroxidase activity found in hepatic, renal, and skeletal muscle of human tissue is not selenium dependent. Glutathione peroxidase activity in human erythrocytes, however, and more importantly in cardiac tissue, contains only the selenium dependent form of the enzyme. $^{22}$

Clinical management of the more severe forms of hyperphenylalaninaemia is dependent on dietary treatment. It is therefore unfortunate that in limiting phenylalanine intake, natural protein intake-and therefore dietary selenium intake-are severely limited too. As selenium is required for the production of glutathione peroxidase protein, children on strict diets may have reduced antioxidant function as a result of reduced enzyme activity. Because the children are given daily vitamin supplements the vitamin $\mathrm{E}$ concentrations may be adequate to spare the selenium requirement under normal circumstances. If, however, the children were subject to severe or prolonged oxidative stress, then the vitamin $\mathrm{E}$ concentrations might be inadequate to cope with the extra antioxidant requirement.

Until recently it was customary to permit children to relax their diets after about 9 years of age, but it is now believed that a stricter diet should be maintained until the child is older, and possibly throughout life. The period of time that these children and young adults are at risk of damage from antioxidant stress is therefore likely to increase. It has been suggested that older patients with cystic fibrosis have an increased risk of developing carcinoma that is associated with lower concentrations of selenium in serum, particularly in the presence of reduced concentrations of vitamin E. ${ }^{23}$ Patients with phenylketonuria may be similarly at risk.

In view of the low concentrations of selenium found in this study, consideration should be given to the addition of selenium to strict therapeutic diets including those used in the treatment of classical phenylketonuria. This would require careful study 
to prevent selenium toxicity and ensure satisfactory bioavailability.

We thank Dr B Keeton, consultant paediatric cardiologist, for examining the four children with phenylketonuria by echocardiography.

\section{References}

${ }^{1}$ Olsen OE, Novacek EJ, Whitehead EI, Palmer IS. Investigations on wheat. Phytochemistry 1970;9:1181-8.

2 Thorling EB, Overvad K, Geboers J. Selenium status in Europe-human data. A multicentre study. Ann Clin Res 1986;18:3-7.

${ }^{3}$ Committee on Dietary Allowances, Food and Nutrition Board. Recommend dietary allowances. 9th ed. Washington: National Academy of Sciences, 1980;162-3.

${ }^{4}$ Thorn J, Robertson J, Buss DH. Trace nutrients. Selenium in British food. Br J Nutr 1978;39:391-6.

5 Diplock AT. Trace elements in human health with special reference to selenium. Am J Clin Nutr 1987;45(suppl):1313-22.

${ }^{6}$ Lombeck I, Kasperak K, Harbisch HD, Feinenedegen LE, Bremer HJ. The selenium state of children. 1. Serum selenium concentration at different ages; activity of glutathione peroxidase of erythrocytes at different ages; selenium content of food of infants. Eur J Pediatr 1977;125:81-8.

${ }^{7}$ Keshan Disease Research Group of the Chinese Academy of Sciences. Epidemiological studies on the etiological relationship of selenium and Keshan disease. Chin Med J 1979;92:477-82.

${ }^{8}$ Chow CK. Nutritional influences on cellular antioxidant defense systems. Am J Clin Nutr 1979;32:1066-81.

${ }^{9}$ Smith I. The hyperphenylalaninaemias. In: Lloyd JK, Scriven $\mathrm{CR}$, eds. Genetic and metabolic disease. London: Butterworths, 1986;166-210.

${ }^{10}$ Lloyd B, Holt P, Delves HT. Determination of selenium in biological samples by atomic absorption spectroscopy. Analyst 1982;107:927-33

1 Beutler E. A manual of biochemical methods: glutathione peroxidase $(G S H-P x)$. 2nd ed. New York: Grune and Stratton, 1979:71-3.
12 Lombeck I. The evaluation of selenium state in children. J Inherited Metab Dis 1983;6(suppl):83-4.

13 Ebert KH, Lombeck I, Kasperak K, Feinendegen LE, Bremer HJ. The selenium content of infant food. Z Ernahrungswiss 1984;23:230-6.

${ }^{14}$ Morris VC, Levander OA. Selenium contents of foods. $J$ Nutr 1970;100:1383-8.

15 Ward KP, Arthur JR, Russell G, et al. Blood selenium content and glutathione peroxidase activity in children with cystic fibrosis, coeliac disease, asthma and epilepsy. Eur J Pediatr 1984;142:21-4.

16 Chen X, Chen X, Yang G, et al. Relation of selenium deficiency to the occurrence of Keshan disease. In: Spallholz JE, Martin $\mathrm{JL}$, Ganther HE, eds. Selenium in biology and medicine. Westport: AVI Publishing, 1981:171-5.

17 Ganther HE, Hafeman DG, Lawrence RA, Serfass RE, Hockstra WG. Selenium in health and disease - a review. In: Prasad AS, ed. Trace elements in human health and disease. Vol 2. New York: Academic Press, 1976:165-234.

18 Prohaska J, Oh SH, Hoekstra WG, Ganther HE. Glutathione peroxidase: inhibition by cyanide and release of selenium. Biochem Biophys Res Commun 1977;74:64-71.

${ }^{19}$ Lombeck I, Kasperak K, Harbisch HD, et al. The selenium state of children. II. Selenium content of serum, whole blood, hair and the activity of erythrocyte glutathione peroxidase in dietetically treated patients with phenylketonuria and maple-syrup-disease. Eur J Pediatr 1978;128:213-23.

${ }^{20}$ Takahashi K, Newburger PE, Cohen HJ. Glutathione peroxidase protein: absence in selenium deficiency states and correlation with enzyme activity. J Clin Invest 1986;77:1402-14.

21 Takahashi K, Cohen HJ. Selenium-dependent glutathione peroxidase protein and activity: immunological investigations on cellular and plasma enzymes. Blood 1986;68:640-5.

${ }^{22}$ Carmagnol F, Sinet PM, Jerome H. Sclenuim-dependent and non-selenium dependent glutathione perioxidases in human tissue extracts. Biochim Biophys Acta 1983;759:49-57.

${ }^{23}$ Stead RJ, Redington AN, Hinks LJ, Clayton BE, Hodson ME, Batten JC. Selenium deficiency and possible increased risk of carcinoma in adults with cystic fibrosis. Lancet 1986;ii:862-3.

Correspondence to Dr B Lloyd, Faculty of Medicine, Southampton General Hospital, Southampton SO9 4XY.

Accepted 26 August 1988 